\title{
ANALISIS IMPLEMENTASI DELAPAN STANDAR NASIONAL PENDIDIKAN DI SEKOLAH MENENGAH PERTAMA (SMP) KABUPATEN SINTANG
}

\author{
Ason $^{1}$, Mardiana ${ }^{2}$ \\ ${ }^{1,2}$ STKIP Melawi \\ Jln. RSUD Melawi, Nanga Pinoh, Kabupaten Melawi, Kalimantan Barat 79672 \\ e-mail: asonyakobus@gmail.com, mardianaleona@gmail.com
}

\begin{abstract}
Abstrak: Menganalisis penerapan delapan standar nasional pendidikan di SMP/MTs Kabupaten Sintang adalah tujuan penelitian ini. Tujuan khusus penelitian adalah untuk mengetahui standar mutu masing-masing sekolah dan kualitas implementasi masing-masing standar nasional pendidikan. Metode penelitian menggunakan pendekatan deskriptif kualitatif. Kepala Sekolah dan Tim Pengembang Sekolah sebagai subjek penelitian dengan kriteria sekolah yang telah terakreditasi. Hasil penelitian adalah penerapan delapan standar nasional pendidikan pada SMP/MTs di Kabupaten Sintang telah terlaksaana dengan baik. Keterlaksanaan 8 Standar Nasioal Pendidikan, berdasarkan data yang diperoleh dari sekolah adalah (1) SMP Negeri 1 Kelam Permai telah mencapai 84\%; (2) SMP Negeri 2 Kelam Permai mencapai 85\%; (3) SMP Negeri 4 Satap 79\%: (4) SMP Negeri 2 Dedai 87\% dan (5) SMP Negeri 8 Dedai 76\% Rata-rata hasil analisis data masing-masing standar menunjukkan bahwa standar isi $89 \%$, standar proses $86 \%$, standar kompetensi lulusan $84 \%$, standar pendidikan dan tenaga $64 \%$, standar sarana dan prasarana $76 \%$, standar pengelolaan $83 \%$, standar pembiayaan $88 \%$, dan standar penilaian pendidikan $87 \%$. Disimpulkan bahwa penerapan delapan standar nasional pendidikan pada SMP/MTs di Kabupaten Sintang telah terlaksana sesuai keadaan yang ada di setiap sekolah.
\end{abstract}

Kata kunci: analisis, penerapan, delapan standard

$\Lambda_{\text {aktivitas penilaian kelayakan }}^{\text {kreditasi merupakan suatu }}$

program satuan pendidikan yang sesuai dan ditetapkan oleh Badan Standar Nasional Pendidikan (BSNP) dan UU Nomor 20 Tahun 2003 tentang Sistem Pendidikan Nasional, pasal 1 ayat (22). Untuk memperoleh kualitas pendidikan, regulasi yang telah ditetapkan oleh pemerintah dan acuan standar untuk mencapai kualitas pendidikan. Sesuai Peraturan Pemerintah Republik
Indonesia Nomor 32 tahun 2013 Tentang Perubahan sesuai Peraturan Pemerintah tentang delapan standar nasional pendidikan Nomor 19 tahun 2005 pasal 1 ayat 1 dan pasal 2 ayat 1 , sebagai pedoman pengembangan kurikulum dalam mencapai tujuan pendidikan nasional.

BSNP merupakan badan bebas yang bertugas melihat mengembangkan, dan mengevaluasi Standar Nasional Pendidikan (PP pasal 32 ayat 28 - 29). 


\section{Bestari: Jurnal Pendidikan dan Kebudayaan \\ Volume 1 Nomor 2 Oktober 2020}

Penerapan delapan standar nasional pendidikan merupakan usaha penting bagi sekolah menengah pertama/ madrasah untuk meningkatkan kualitas pendidikan yang dipimpinnya.

Mengacu pada pernyataan regulasi tersebut adapun permasalahannya adalah "Bagaimana implementasi delapan Standar Nasional Pendidikan di Sekolah Menengah Pertama (SMP) Kabupaten Singtang?" Untuk menjawab permasalahan ini peneliti mengadakan survey ke lima (5) SMP/MTs di Kabupaten Sintang, yang telah diakreditasi oleh BAN-S/M tahun 2019. Adapun tujuan penelitian ini untuk menganalisis penerapan delapan standar nasional pendidikan pada jenjang SMP/MTs Kabupaten Sintang. Tujuan khusus penelitian adalah untuk mengetahui standar mutu masing-masing sekolah mengacu pada standar nasional pendidikan dan kualitas implementasi setiap standar nasional pendidikan.

Berdasarkan PP No. 19 Tahun 2005 mengenai Standar Nasional Pendidikan pasal 2 ayat (1) menyatakan lingkup SNP terdiri dari: 1) standar isi, 2) standar proses, 3) standar kompetensi lulusan, 4) standar pendidik dan tenaga kependidikan, 5) standar sarana dan prasarana, 6) standar pengelolaan, 7) standar pembiayaan, dan 8) Standar penilaian pendidikan.

Implementasi delapan standar nasional pendidikan tersebut merupakan acuan dalam kegiatan akreditasi sekolah/madrasah. Dengan adanya akreditasi dapat memotivasi dan mewujudkan hasil yang diinginkan bagi perkembangan pendidikan dan mengarahkan untuk melakukan penjaminan mutu sekolah/madrasah secara kontinyu untuk mencapai mutu yang diinginkan.

\section{METODE PENELITIAN}

Pendekatan yang digunakan dalam penelitian ini yaitu denganmetode deskriptif kualitatif. Kepala sekolah dan Tim Pengembangan Sekolah pada 5 SMP yang telah diareditasi di Kabupaten Sintang yang menjadi subjek penelitian. Data yang dikumpulkan melalui teknik observasi, wawancara dan dokumentasi. Analisis data menggunakan empat tahapan, terdiri dari pengumpulan data, reduksi data, penyajian data, dan kesimpulan.

Teknik pengumpulan data dalam penelitian ini menggunakan lembaran observasi, wawancara, dan dokumentasi, kemudian dianalisis secara deskriptif kualitatif. Teknik observasi adalah 


\section{Bestari: Jurnal Pendidikan dan Kebudayaan \\ Volume 1 Nomor 2 Oktober 2020}

pengumpulan data melalui pengamatan terhadap situasi dan kondisi sekolah menyangkut pelaksanaan 8 standar nasional pendidikan. Sedangkan wawancara adalah sebuah cara khusus dalam setting percakapan yang terstruktur dalam rangka verifikasi dan validasi data yang diperlukan. Dokumen yang diperlukan dalam penelitian ini berupa delapan standar nasional pendidikan, yaitu dokumen-dokumen standar (1) Standar Isi, (2) Standar Proses Pembelajaran, (3) Standar Kompetensi Lulusan, (4) Standar Pendidik dan Tenaga Kependidikan, (5)Standar sarana dan Prasarana, (6) Standar Pengelolaan, (7) Standar pembiayaan, (8) dan Standar Peilaian pendidikan

Analisis data menggunakan prinsip-prinsisp deskriptif (Sukardi, 2009: 86). Tahapan dalam analisis data terdiri dari: pengumpulana data, reduksi data, penyajian data dan penarikan kesimpulan. Berikut ini penjelasan dari tahapan tersebut:

\section{Pengumpulan Data}

Merupakan proses pencarian data yang dilakukan dengan cara melakukan pengamatan, wawancara, serta verifikasi dan validasi terhadap dokumentasi yang berkaitan dengan delapan standar nasional pendidikan yang tersedia oleh sekolah/madrasah yang dijadikan sebagai contoh penelitian.

2. Penyajian Data

Merupakan kegiatan menyusun data yang telah dipilah dalam bentuk narasi tersusun secara sistematis sesuai dengan rumusan masalah. Data yang di sampaikan berupa tabel.

Sajian data yang disampaikan berupa tabel dan analisis dari data pada tabel tersebut yang berupa narasi. Hal ini dimaksudkan agar pembaca penelitian ini dapat memahami isi penelitian dengan lebih jelas.

3. Penarikan Kesimpulan dan Verifikasi

Penarikan kesimpulan adalah kegiatan akhir yang menggambarkan seluruh kegiatan secara utuh dalam suatu penelitian. Sedangkan verifikasi merupakan usaha dalam mencari makna terhadap data yang diperoleh dengan cara mencari pola, hubungan, tema, persamaan dan hal-hal lain sering muncul.

\section{HASIL PENELITIAN}

Berdasarkan hasil survey yang dilakukan peneliti di lima SMP Kabupaten Sintang yang telah diakreditasi tahun 2019, diperoleh hasil bahwa pelaksanaan Manajemen Berbasis Sekolah (MBS) belum 


\section{Bestari: Jurnal Pendidikan dan Kebudayaan}

Volume 1 Nomor 2 Oktober 2020

sepenuhnya dapat dilaksanakan. Hal ini dapat dilihat dari kesiapan sekolah dalam menghadapai akreditasi sekolah di mana dokumen-dokumen setiap standar yang disiapkan hanyalah administratif sifatnya. Sebagai contoh, Rencana Pelaksanaan Pembelajaran (RPP).

Hampir semua guru mempunyai dokumen perangkat perencanaan pembelajaran, akan tetapi tidak sesuai dengan perencanaan pembelajaran yang di buat. Dalam penyampaian materi pembelajaran Guru hanya ingin mencapai target kurikulum, dan tidak untuk mencapai kompetensi. Guru mengajar berdasarkan buku paket/buku teks, dan bukan berdasarkan RPP yang mereka susun. Model evaluasi dan penentuan nilai pembelajaran menitikberatkan pada hasil belajar. Sehingga mengesampingkan proses evaluasi. Sarana dan prasarana sudah cukup memadai untuk menunjang pembelajaran, akan tetapi pemanfaatannya belum optimal. Dalam melaksanakan pembelajaran guru hanya mengandalkan buku pegangan untuk menyampaikan materi. Laboratorium cenderung tidak dimanfaatkan, media banyak tidak terpakai sehingga menyebabkan kerusakan. Selain itu, kurangnya kepedulian masyarakat terhadap program-program sekolah, dikarenakan tidak adanya kesesuaian antara visi, misi dan tujuan sekolah dengan orang tuasiswa. Penyusunan program dan kegiatan yang sekolah susun tidak sesuai dengan situasi, kondisi, kebiasaan, karakter masyarakat setempat.

Berdasarkan data jumlah SMP/MTs Kabupaten Sintang yang diakreditasi tahap 1 tahun 2019, secara umum penerapan delapan standar nasional pendidikan pada jenjang SMP/MTs Kabupaten Sintang sudah memenuhi Standar Nasional. Hal ini tampak dengan adanya kesesuaian antara hasil penelitian dengan hasil akreditasi yang dicapai oleh sekolah yaitu menunjukkan peringkat $\mathrm{C}$ dan $\mathrm{B}$ sesuai dengan kondisi lima sekolah yang dijadikan sampel penelitian. Hal ini tampak pada tabel berikut ini: 
Bestari: Jurnal Pendidikan dan Kebudayaan

Volume 1 Nomor 2 Oktober 2020

Tabel 1. Hasil Akreditasi Lima (5) Sekolah

\begin{tabular}{llllllllllll}
\hline & \multicolumn{1}{c}{ NAMA } & \multicolumn{1}{c}{ STANDAR } \\
$\mathrm{N}$ & \multicolumn{1}{c}{ SEKOLAH } & 1 & 2 & 3 & 4 & 5 & 6 & 7 & 8 & $\begin{array}{l}\text { Rerat } \\
\mathrm{a}\end{array}$ \\
\cline { 3 - 11 } & & 91 & 92 & 84 & 64 & 82 & 83 & 95 & 82 & 84 \\
\hline 1 & $\begin{array}{l}\text { SMP Negeri 1 Kelam } \\
\text { Permai }\end{array}$ & & & & & & & & & \\
2 & SMP Nnegeri 2 Kelam & 94 & 94 & 76 & 72 & 78 & 90 & 89 & 93 & 85 \\
& $\begin{array}{l}\text { Permai } \\
3\end{array}$ & $\begin{array}{l}\text { SMP Negeri 4 Satap } \\
\text { Kelam Permai }\end{array}$ & 89 & 75 & 84 & 62 & 65 & 90 & 82 & 84 & 79 \\
4 & $\begin{array}{l}\text { SMP Negeri 2 Dedai } \\
5\end{array}$ & 92 & 90 & 96 & 69 & 85 & 84 & 95 & 88 & 87 \\
\hline & SMP Negeri 8 Dedai & 82 & 81 & 81 & 54 & 71 & 70 & 81 & 88 & 76 \\
\hline
\end{tabular}

Berdasarkan data pada tabel $1 \mathrm{di}$ atas, tampak bahwa lima SMP/MTs Kabupaten Sintang yang dijadikan sampel penelitian menunjuikan kualifikasi mutu yang berbeda-beda. Kualifikasi tersebut mengacu pada peringkat akreditasi yang dicapai oleh sekolah masing-masing. Sebagaimana tampak pada tabel 1, menunjukkan bahwa : (1) SMP Negeri 1 Kelam Permai telah melaksanakan 8 standar nasional pendidikan dengan skor rata-rata 84, kualifikasi Baik; (2) SMP Negeri 2 Kelam Permai mencapai skor rata-rata 85, kualifikasi Baik; (3) SMP Negeri 4 Satap Kelam Permai mencapai skor 79, kualifikasi Cukup; (4) SMP Negeri 2 Dedai mencapai skor 87, dengan kualifikasi Baik;dan (5) SMP Negeri 8 Dedai memperoleh skor 76 , kualifikasi Cukup.

Mengacu pada tabel 1 di atas pula, pada umumnya penerapan delapan standar nasional pendidikan pada SMP/MTs Kabupaten Sintang dilihat dari masing-masing stadar adalah sebagai berikut: (1) Standar Isi mencapai 89\%, (2) Standar Proses Pembelajaran adalah 86\% (3) Standar Kompetensi Lulusan yaitu 84\%; (4) Standar Pendidik dan Tenaga Kependidikan 64\%, (5)Standar sarana dan Prasarana yaitu $76 \%$, (6) Standar Pengelolaan 83\% (7) Standar pembiayaan adalah $88 \%$, (8) dan Standar Penilaian pendidikan $87 \%$. Data-data tersebut dapat disajikan pada diagram pada gambar 1 di bawah ini

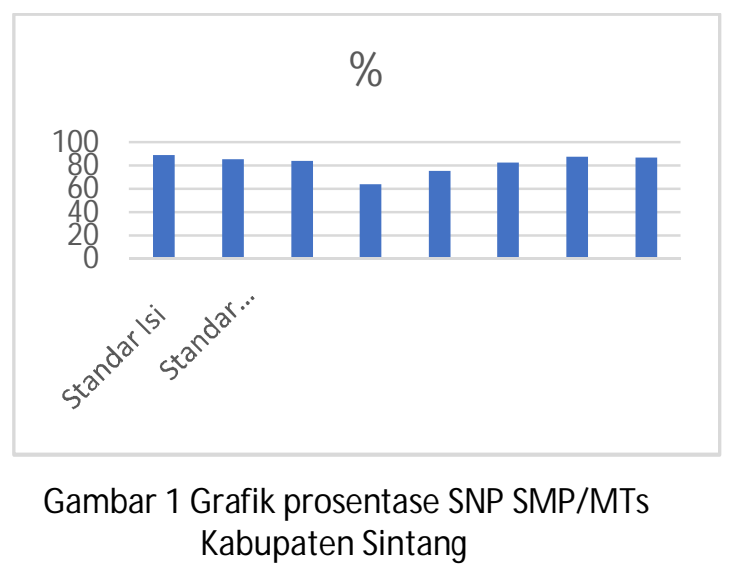




\section{Bestari: Jurnal Pendidikan dan Kebudayaan}

Volume 1 Nomor 2 Oktober 2020

Mengacu pada gambar grafik di atas, dari delapan standar nasional pendidikan yang telah dilaksanakan pada SMP/MTs Kabupaten Sintang, standar 4yaitu pendidikan dan tenaga kependidikan dan standar 5 Sarana dan Prasarana perlu mendapat perhatian, karena kedua standar ini masih berada pada kualifikasi Cukup yakni C. Untuk Standar yang lain sudah Baik atau B, tinggal meningkatkannya menjadi kualifikasi Sangat Baik yaitu A.

Berdasarkan table dan grafik di atas maka di jelaskan masing-masing standar berikutini :

1. Standar Isi

Standar ini sudah mencapai 89\% karena kecerdasan sikap sosial, pengetahuan, spiritual dan keterampilan pada standar isi telah dilengkapi dengan perangkat pembelajaran guru. Terdapat dokumen kurikulum dan dokumen proses, tahapan dan prosedur pengembangan kurikulum.

Kualifikasi standar isi sudah baik, namun perlu ditingkatkan terutama dokumen yang belum lengkap, yaitu: daftar hadir, notulen rapat, berita acara, penetapan, dan pengesahan kurikulum yang berlaku.
2. Standar Proses Pembelajaran

Standar ini telah mencapai $86 \%$ karena sekolah telah mengembangkan silabus dan RPP yang memuat komponen-komponen silabus dan RPP. Guru telah melaksanakan standar proses dengan benar, mengacu pada SK, KD, indikator dan tujuan pembelajaran setiap mata pelajaran, yang tersusun secara sistematis, dengan waktu dan beban belajar siswa yang sesuai. Kualifikasi standar proses sudah baik, perlu ditingkatkan terus menerus terutama setiap pembelajaran hendaknya diakhiri dengan penilaian proses dan didukung oleh supervisi kepala sekolah secara teratur dan terjadwal.

3. Standar Kompetensi Lulusan

Standar kompetensi lulusan mencapai 84\%, karena sudah mencerminkan sikap beriman dan bertakwa, sikap sosial dengan karakter, gerakan literasi, perilaku sehat jasmani dan rohani. Aktivitas yang menampakkan keterampilan bertindak secara individu, komunikatif dan kolaboratif sudah baik, hanya perlu terus-menerus dilaksanakan sehingga menjadi suatu kebiasaan yang baik pula. 


\section{Bestari: Jurnal Pendidikan dan Kebudayaan \\ Volume 1 Nomor 2 Oktober 2020}

Pengetahuan yang dikembangkan sekolah terdiri dari pengetahuan fakta, konsep, prosedur, dan metakognitif, perlu dikuasai guru agar kegiatan pembelajaran menunjukkan dimensi kemampuan siswa untuk berpikir kreatif, produktif, dan kritis belum tampak. Kualifikasi standar lulusan sudah baik, perlu ditingkatkan terus dan dikembangkan agar sikap spiritual, sikap sosial, pengetahuan dan keterampilan siswa menjadi terinternalisasi pada diri siswa.

4. Standar Pendidik dan Tenaga

Kependidikan

Semua sekolah memiliki masalah yang sama pada standar pendidik dan tenaga kependidikan (Tendik). Secara umum jumlah guru belum mencukupi, meskipun kualifikasi guru sudah sesuai dengan tuntutan undang-undang. Namun, belum semua guru mendapat sertifikat pendidik. Akan tetapi setiap guru berupaya mengembangkan kompetensi pedagogik, kepribadian, sosial, dan professional. Masalah yang cukup penting yang perlu mendapat perhatian pemerintah adalah semua sekolah belum memiliki konselor/guru BK secara khusus yang sesuai dengan keahlian/ilmu. Atas dasar ini pula maka kualifikasi standar Tendik pada semua sekolah sangat rendah yakni hanya mencapai $64 \%$.

5. Standar Sarana dan Prasarana yaitu $76 \%$,

Kondisi lahan sekolah sudah sangat memadai dan luasnya memenuhi persyarat. Luas lantai bangunan juga sudah sangat baik, memenuhi syarat keselamatan dankesehatan, Sekolah perlu mengusahakan tempatt parkir dan gudang secara khusus. Namun ada pula sekolah yang kondisi lahan sekolah tidak jelas dan tidak memiliki sertifikat atau surat keterangan tanah. Prasarana lain yang diperlukan disediakan oleh sekolah seperti ruang administrai, perpustakaan, UKS, Gudang, Laboratorium. Perlu pemeliharaan dan penatan yang baik Kuantitas standar Sarpras, masih kurang dan perlu ditambahagar kegiatan pembelajaran bisa berjalan dengn lancar. Atas dasar itu maka kualifikasi standar ini hanya $76 \%$

6. Standar Pengelolaan

Standar pengelolaan sudah baik mencapai 83\%. Pada umumnya sekolah memiliki visi, misi, dan tujuan disertai program kerja tahun 


\section{Bestari: Jurnal Pendidikan dan Kebudayaan \\ Volume 1 Nomor 2 Oktober 2020}

dan program kerja jangka menengah.

Sekolah memiliki dokumen

pengelolaan pendidikan dan struktur organisasi serta pembagian tugas guru dan tenaga kependidikan. Kualifikasi standar pengelolaan sudah baik, namun visi, misi dan tujuan sekolah pelu dilengkap dengan domumen, penyusunan, penetapan dan sosialisasi berupaberita acara, penetapan, dan daftar hadir.

7. Standar Pembiayaan

Semua anggaran biaya untuk item kegiatan sekolah sudah disusun dalam RKAS secara sistematis, dan dilaksanakan sesuai dengan program yang direncanakan, serta dilaporkan secara berkala sesuai dengan ketentuan. Kualifikasi standar pembayaan sudah baik didukung oleh dokumen perencanaan, pelaksanaan dan, evaluasi yang baik, hanya perlu dilengkapi tindak lanjut hasil evaluasi. Oleh karena itu kualifikasi standar ini telah mencapai $88 \%$.

8. Standar Penilaian/Evaluasi

Standar in sudah mencapai $87 \%$. Prinsip penilaian sudah mendapat perhatian semua guru, demikian juga penentuan kriteria ketuntasan minimal. Hanya perlu kelengkapan dokumen proses penentuan KKM.
Bentuk pelaksanaan penilaian pengetahuan, sikap, dan keterampialan sudah memenuhi syarat kualifikasi standar penilaian sudah baik, perlu dipertahankan bahkan dikembangkan terus menerus, terutama kisi-kisi instrumen ulangan harian, penilaian sikap, dan keterampilan.

\section{SIMPULAN}

Penelitian ini menunjukkan penerapan delapan standar nasional pendidikan pada SMP/MTs di Kabupaten Sintang telah dilaksanakan dengan baik. Keterlaksanaan delapan Standar Nasioal Pendidikan, berdasarkan data yang diperoleh dari sekolah sampal adalah (1) SMP Negeri 1 Kelam Permai telah mencapai 84\%; (2) SMP Negeri 2 Kelam Permai mencapai 85\%; (3) SMP Negeri 4 Satap 79\% : (4) SMP Negeri 2 Dedai 87\% dan (5) SMP Negeri 8 Dedai $76 \%$

\section{UCAPAN TERIMA KASIH}

Dengan tersusunnya artikel ilmiah dengan judul "Analisis Implementasi Delapan Standar Nasional Pendidikan Di Sekolah Menengah Pertama Kabupaten Sintang" maka Peneliti mengucapkan terima kasih kepada para Kepala Sekolah dan guru yang Peneliti jadikan subjek dalam 


\section{Bestari: Jurnal Pendidikan dan Kebudayaan \\ Volume 1 Nomor 2 Oktober 2020}

penelitian. Semoga kebaikan Bapak dan

Ibu Kepala Sekolah serta para guru mendapatkan berkat yang berlimpah dari Tuhan Yang Maha Kasih.

\section{DAFTAR PUSTAKA}

Malik, A. (2019). Prosedur Operasional Standar Pelaksanaan AkreditasiSekolah/Madrasah.

Jakarta: Badan Akreditasi Nasional Sekolah/Madrasah.

Ason dan Saputro, E. F. H. (2019).

"Studi Implementasi Standar

Proses Dalam Pembelajaran

Kurikulum 2013 Pada Guru

Sekolah Dasar Kapuaten

Melawi”, Jurnal Pendidikan

Dasar, Volume 7 No 2. Tersedia di

http://jurnalstkipmelawi.ac.id/inde

x.php/JPD/issue/view/28. diunduh

tanggal 29 April 2020

Kemendiknas. (2011). Analisis Sistem

Akreditasi Sekolah/Madrasah.

Jakarta: Kemendiknas

Badan Akreditasi Nasional Sekolah/ Madrasah (BAN-SM). (2016).

Pedoman Akreditasi Sekolah/

Madrasah 2016. Jakarta: Badan

Akreditasi Nasional Sekolah/

Madrasah (BAN-SM).

Herdiansyah, H. (2012). Metodologi

Penelitian Kualitatif untuk
Ilmu-ilmu Sosial. Jakarta Selatan : Salemba Humanika.

Keputusan Badan Akreditasi Nasional Sekolah/ Madrasah Nomor 082/BAN/SM/SK/2018 tentang Prosedur Operarional Standar Sugiyono. (2015). Metode Penelitian Kuantitatif dan Kualitatif dan $R \& D$. Bandung. Alfabeta

Suliyanto. (2009). Metode Riset Bisnis.

Edisi II. Penerbit Andi Yogyakarta. Yogyakarta.

Permendiknas Nomor 24 Tahun 2007 tentang Standar Sarana Prasarana

Permendiknas Nomor 19 Tahun 2007 tentang Standar Pengelolaan

Permendiknas Nomor 69 Tahun 2009 tentang Standar Pembiayaan

Permendikbud Nomor 28 Tahun 2016 tentang Sistem Penjaminan Mutu Pendidikan

Permendikbud Nomor 21 Tahun 2016 tentang Standar Isi

Permendikbud Nomor 22 Tahun 2016 tentang Standar Proses

Permendikbud Nomor 23 Tahun 2016 tentang Standar Penilaian

Permendikbud Nomor 24 Tahun 2016 tentang Kompetensi Dasar

Undang- Undang Nomor 20 Tahun 2003 BAB XVI Pasal 60 tentang 
Bestari: Jurnal Pendidikan dan Kebudayaan

Volume 1 Nomor 2 Oktober 2020

Evaluasi, Akreditasi dan

Sertifikasi. Jakarta: Depdiknas.

Undang-Undang Nomor 20 Tahun 2003

tentang Sistem Pendidikan

Nasional. Jakarta: Depdiknas 


\title{
Bestari: Jurnal Pendidikan dan Kebudayaan
}

Volume 1 Nomor 2 Oktober 2020

\section{MODEL PERMAINAN KREATIF UNTUK MEMOTIVASI SISWA DALAM PEMBELAJARAN BOLA VOLI PADA SISWA KELAS V SD}

\author{
Roni Albar ${ }^{1}$, KhairilAkbar ${ }^{2}$, Indria Susilawati ${ }^{3}$ \\ ${ }^{1}$ Mahasiswa Lulusan Program Studi Penjaskesrek Tahun 2018 \\ ${ }^{2,3}$ Dosen STKIP Melawi
}

Jl. RSUD Melawi km. 04 Kec.Nanga Pinoh Kab. Melawi Kalimantan Barat ronialbar.75@gmail.com, khairilakbar89@gmail.com,smile_indria@yahoo.com

\begin{abstract}
The general objective of this study is to motivate students in learning the bottom service volleyball game for grade V students of SD Negeri 09 Tanjung Lay. Specific purpose is to find out how much influence the creative game model has on students' motivation in volleyball games in grade V 09 Tanjug Lay Elementary School.This study uses classroom action research (Clasroom action research) using action cycles. In this action research, using the models described are: Planning (Action), Action (Action), Observation (Observation) and Reflection (Reflection).The findings of the study were: the results of student motivation increased, because in the first cycle the average value of students was 57.73 while in the second cycle the average value of students was 74.54 had reached the predetermined criteria.Based on the results of the study it can be concluded that through creative game models can motivate students in learning volleyball games in class $\mathrm{V}$ SD Negeri 09 Tanjung Lay. In this study, it can be suggested, the health teacher is expected to be able to plan and develop creativity and be more innovative in the learning process in an effort to improve student competencies, especially in choosing learning methods.
\end{abstract}

Key Words: Creative Games, Volleyball

Abstrak: Tujuan umum dari penelitian ini yaitu untuk memotivasi siswa dalam pembelajaran permainan bola voli pada siswa kelas V SD Negeri 09 Tanjung Lay. Tujuan khusus adalah Untuk mengetahui seberapa besar pengaruh model permainan kreatif terhadap motivasi siswa dalam permainan bola voli kelas V SD Negeri 09 Tanjug Lay. Penelitian ini menggunakan penelitian tindakan kelas (Clasroom action research) dengan menggunakan siklus tindakan. Pada penelitian tindakan ini, menggunakan model yang dijelaskan yaitu: Rencana (Planning), Tindakan (Action), Pengamatan (Observation) dan Refleksi 


\section{Bestari: Jurnal Pendidikan dan Kebudayaan \\ Volume 1 Nomor 2 Oktober 2020}

(Reflection).Hasil temuan penelitian adalah : hasil motivasi siswa meningkat, karena pada siklus I nilai rata - rata siswa adalah 57.73 sedangkan pada siklus II nilai rata-rata siswa adalah 74.54 telah tercapai kriteria yang telah ditetapkan.Berdasarkan hasil penelitian dapat disimpulkan bahwa melalui model permainan kreatif dapat memotivasi siswa dalam pembelajaran permainan bola voli pada siswa kelas V SD Negeri 09 Tanjung Lay.Dalam penelitian ini, dapat disarankan, guru penjaskes diharapkan dapat merencanakan dan mengembangkan kreativitas dan lebih inovatif pada proses pembelajaran dalam upaya meningkatkan kompetensi siswa terutama dalam memilih metode pembelajaran.

Kata Kunci : Permainan Kreatif, Bola Voli

$\sqrt{\text { melaksanakan observasi di }}$ Sekolah Dasar Negeri 09 Tanjung Lay, peneliti menemukan bahwa banyak sekali model permainan atau cara mengajar yang dilakukan oleh guru di lapangan maupun dalam ruangan, yakni sebagai guru penjasorkes. Dalam mengajar di lapangan maupun dalam ruangan, tentunya seorang guru perlu memahami minat siswa dalam pembelajaran sehingga dapat memilih model permainan yang tepat.

Motivasi siswa dalam mengikuti pelajaran Penjasorkes dapat disebabkan oleh beberapa faktor, antara lain hobi siswa itu sendiri, ada yang ingin menjaga kesehatan badannya, dan ada juga yang ingin meluapkan kejenuhannya di lapangan dengan cara bermain bersama teman sebayanya.
Seseorang melakukan aktivitas karena didorong oleh adanya faktor-fakor, kebutuhan biologis, insting, dan unsur-unsur kejiwaan yang lain memotivasi siswa dapat dilihat dari kesungguhan dalam mengerjakan aktivitas yang guru berikan. Apabila seorang siswa dalam melakukan suatu gerakan dengan rasa senang dan sungguh-sungguh, maka dapat disimpulkan siswa tersebut memiliki motivasi yang tinggi dalam melakukan gerakan atau aktivitas yang guru berikan.

Berdasarkan anggapan di atas, tentu saja akan mempengaruhi motivasi siswa dalam mengikuti pembelajaran Penjasorkes. Hal tersebut menguatkan fakta di lapangan bahwa masih ditemukan adanya siswa yang belum mengoptimalkan waktu pembelajaran 


\section{Bestari: Jurnal Pendidikan dan Kebudayaan \\ Volume 1 Nomor 2 Oktober 2020}

dengan sebaik mungkin. Keadaan tersebut bisa dilihat dengan adanya siswa yang kurang antusias dalam mengikuti pelajaran. Siswa yang menganggap Penjasorkes tidak terlalu penting lebih memilih untuk duduk, berteduh, dan mengobrol pada saat proses pembelajaran berlangsung bahkan ada juga yang asyik bergurau dan bermain sendiri.

Pengenalan teknik dasar sangatlah penting dalam pembelajaran pendidikan jasmani untuk memudahkan proses balajar mengajar untuk tercapainya materi yang di sampaikan secara utuh dan juga untuk meningkatkan keterampilan gerak serta prestasi belajar siswa. Sehubungan dengan hal tersebut di atas maka peneliti tertarik untuk melakukan penelitian dengan judul "Model Permainan Kreatif untuk Memotivasi Siswa dalam Permainan Bola Voli Kelas V SD Negeri 09 Tanjung Lay”.

Berdasarkan latar belakang diatas maka identifikasi masalah pada penulisan ini ialah sebagai berikut: (1) Siswa kurang antusias dalam mengikuti proses pembelajaran karena pembelajaran yang berlangsung cenderung membosankan. (2) Siswa hanya dituntut untuk mendengarkan penjelasan dari guru sehingga menyebabkan siswa kurang aktif. (3) Saat proses pembelajaran berlangsung, beberapa siswa tidak serius dalam mengikuti pembelajaran. Berdasarkan latar belakang yang telah diuraikan diatas, maka peneliti dapat merumuskan permasalah adalah (1) Bagaimana model permainan kreatif untuk memotivasi siswa dalam permainan bola voli pada siswa kelas $\mathrm{V}$ SD Negeri 09 Tanjung Lay?., (2) Seberapa besar siswa termotivasi terhadap permaianan bola voli dengan model permainan kreatif?

Permainan bola voli adalah olahraga yang dapat dimainkan oleh anak-anak sampai orang dewasa wanita maupun pria. Dengan bermain bolavoli akan berkembang secara baik unsur-unsur daya pikir kemampuan dan perasaan. Di samping itu kepribadian juga dapat berkembang dengan baik terutama control pribadi, disiplin, kerjasama, dan rasa tanggung jawab terhadap apa yang diperbuatnya.

Teknik adalah cara melakukan atau melaksanakan sesuatu untuk 


\section{Bestari: Jurnal Pendidikan dan Kebudayaan}

Volume 1 Nomor 2 Oktober 2020

mencapai tujuan tertentu secara efektif dan efisien.Teknik dasar dalam permainan bola voli terdiri dari teknik servis, teknik pas, teknik umpan, teknik smash dan teknik bendungan.

Bermain adalah melakukan sesuatu untuk bersenang-senang dan permainan adalah bermain Poewadarminta, (2003:689). Telah diakui kebenarannya bahwa hidup manusia sejak dari kecil tumbuh dengan melewati beberapa macam bentuk pengalaman bermain.Dari mempelajari perkembangan individu manusia beserta sejarahnya, dapat ditarik kesimpulan bahwa permainan itu ada. Oleh karena itu manusia tumbuh tidak dapat mengelakkan alam permainan. Anak-anak berkembang melewati bermacam-macam permainan sebagai kodrat yang alami Soemitro (1992:3).

Jadi bermain juga mengandung unsur pendidikan dimana dalam melakukan permainan bisa melatih anak untuk lebih kreatif dalam menentukan sesuatu tindakan, mengembangkan daya tangkap serta imajinasinya dapat berkerja sama, melatih kejujuran dan meningkatkan jiwa sosial.

Dari pendapat para ahli di atas dapat disimpulkan bahwa permainan adalah bagian dari kehidupan anak dan aktifitas bermain yang dilakukan dalam rangka mencari kesenangan serta kepuasan, namun bisa ditandai pencarian menang-kalah.Dalam penelitian ini peneliti ingin memotivasi siswa dengan menggunakan permainan 4 on 4 dalam pembelajaran bolavoli khususnya siswa kelas V SD Negeri 09 Tanjung Lay.

Aspek motivasi memegang peranan dalam kejiwaan seseorang, sebab motivasi merupakan salah satu faktor penentu sebagai pendorong tingkah laku manusia, sehingga dengan adanya motivasi seseorang dapat mendorong dirinya untuk lebih giat berlatih dan mencapai hasil yang maksimal. Menurut Uno (2014:1) motivasi adalah dorongan yang menggerakkan seseorang bertingkah laku, dorongan ini berada pada diri seseorang yang menggerakakkan untuk melakukansesuatu yang sesuai dengan dorongan dalam dirinya. Pendapat lain dari Walgito (2003: 220), mengatakan 


\section{Bestari: Jurnal Pendidikan dan Kebudayaan \\ Volume 1 Nomor 2 Oktober 2020}

bahwa motivasi adalah sebuah keadaan

individu atau organisme yang mempengaruhi perilaku ke arah tujuan. Menurut Gunarsa (2008: 47) motivasi adalah suatu kekuatan atau tenaga pendorong untuk melakukan sesuatu hal atau menampilkan sesuatu prilaku tertentu.

Berdasarkan beberapa pendapat parah ahli di atas, dapat disimpulkan bahwa motivasi adalah seluruh proses gerakan termasuk situasi yang mendorong berupa dorongan, pengerak atau alasan yang timbul dan terdapat dalam diri seseorang untuk bereaksi/tidak bereaksi untuk menentukan arah aktivitas terhadap pencapaian tujuan.

\section{METODE PENELITIAN}

\section{Pelaksanaan Penelitian}

Metode dalam suatu penelitian harus tepat atau mengarah pada tujuan penelitian serta dapat di pertanggung jawabkan secara ilmiah sesuai dengan aturan yang berlaku, agar dalam penelitian tersebut dapat diperoleh hasil yang sesuai dengan yang diharapkan. Metode penelitian yang digunakan dalam penelitian ini adalah penelitian tindakan kelas. Dengan penelitian tindakan kelas peneliti dapat mencermati suatu obyek dalam hal ini siswa, menggunakan permainan kreatif untuk memotivasi siswa terhadap pembelajaran bola voli. Melalui tindakan yang sengaja dilakukan dengan tujuan tertentu dalam bentuk rangkaian siklus kegiatan. Dengan demikian perkembangan dalam setiap kegiatan dapat terpantau.

\section{Subjek, Objek dan Waktu Penelitian}

Subjek adalah siswa kelas V SD Negeri 09 Tanjung Lay dengan jumlah siswa sebanyak 11 orang, terdiri dari 6 orang siswa perempuan dan 5 orang siswa laki-laki. Sedangkan yang menjadi objek dalam Penulisan ini adalah memotivasi siswa pada permainan bola voli dengan model permainan kreatif

\section{Waktu Pelaksanaan Penelitian}

Penelitian ini dilaksanakan pada SD Negeri 09 Tanjung Lay.Alasan penulis memilih tempat penelitian tersebut, karena peneliti pernah melakukan praktek lapangan di sekolah tersebut.

\section{Prosedur Penelitian}

Pelaksanaan Penelitian Tindakan Kelas ini melalui beberap tahapan 


\section{Bestari: Jurnal Pendidikan dan Kebudayaan \\ Volume 1 Nomor 2 Oktober 2020}

tahapan tersebut terdiri dari perencanaan tindakan, pelaksanaan tindakan, pengamatan tindakan, dan refleksi tindakan sebagai berikut :

Pada setiap siklus.

\section{Perencanaan tindakan}

Membuat rencana pembelajaran dengan mengacu kepada tindakan yang diterapkan dalam penelitian tindakan kelas. Instrumen yang digunakan dalam siklus tindakan kelas. Penyusunan alat evaluasi pembelajaran.

\section{Pelaksanaan Tindakan}

Deskripsi tindakan yang akan dilakukan, sekenario kerja tindakan dan prosedur tindakan yang diterapkan.

\section{Observasi}

Peneliti

pengetahuan selama

mengobservasi pembelajaran berlangsung guru sebagai peneliti melakukan penilaian mengunakan lembar pengamatan yang dilakukan oleh teman sejawat.

\section{Repleksi}

Tahapan refleksi ini guru selaku peneliti mengumpulkan data hasil observasi atau evaluasi yang telah dilaksanankan untuk dianalisis dan diproses sehingga pada akhirnya dapat ditemukan suatu hasil terhadap kegiatan pembelajaran yang telah berlangsung dan akan diketahui apakah terdapat peningkatan.

\section{HASIL DAN PEMBAHASAN}

Berdasarkan tujuan peneliti lakukan maka tujuan yang ingin dicapai dalam penelitian ini adalah; untuk mengetahui peningkatan motivasi pembelajaraan bola voli khususnya dalam permainan bola voli melalui model permainan kreatif pada siswa kelas V SD Negeri 09 Tanjung Lay.

Penelitian tindakan kelas ini dilakasanakan di SD Negeri 09 Tanjung Lay yaitu pada kelas V yang berjumlah 11 orang siswa, dalam penelitian ini dilakukan dalam dua tahapan yaitu siklus I dan siklus II. Pada pembelajaran meningkatan motivasi siswa pada permainan bola voli dengan model permainan kreatif. Setiap siklus terdiri dari perencanaan, pelaksanaan, observasi dan refleksi. Berdasarkan tujuan penelitian yang penulis lakukan maka sasaran yang akan dicapai adalah untuk 


\section{Bestari: Jurnal Pendidikan dan Kebudayaan}

Volume 1 Nomor 2 Oktober 2020

meningkatkan motivasi siswa pada pembelajaraan perminanbola voli.

Siklus pertama dilaksanakan selama satu kali pertemuan yaitu dengan materi pokok permainan bola besar yaitu permainan bola voli yang dibahas pada pertemuan ini adalah memotivasi siswa pada pembelajaran permianan bola voli. Siklus pertama yang dilaksanakan satu kali pertemuan ini, dihadiri oleh 11 siswa.Kriteria keberhasilan siswa ditetapkan bila nilai 60. Tindakan yang dilakukan pada siklus ke-1 ini, yaitu: Proses pembelajara mengunakan model permainan kreatif,setelah siswa di ajarkan pembelajaran permainan kreatif dan selanjut setiap siswa melakukan permainan bola voli.

Dari kegiatan pembelajaran tersebut peneliti mendapat hasil yang dilakukan selama proses kegiatan pembelajaraan meningkatkan motivasi siswa pada pelajaran permai nan bola voli. Nilai rata-rata yang di peroleh siswa pada siklus I adalah 54,72. Pada siklus I ini masih belum mencapai nilai kriteria ketuntasan minimal.

Data tersebut diatas menunjukan bahwa pembelajaran meningkatkan motivasi siswa dalam pelajaran permainan bola dari jumlah siswa sebanyak 11 orang hanya ada 4 orang siswa yang dinyatakan tuntas dalam proses pembelajaaraan tersebut. Nilai motivasi siswa pada pembelajaraan bola voli yang paling tertinggi adalah 80 dan yang terendah adalah 40 . Jumlah nilai siswa keseluruhannya 630 dibagi 11 Orang maka nilai rata-rata adalah 57.73 Dengan demikian rata-rata nilai motivai siswa pada pembelajaraan bola voli siklus pertama siswa masih kurang termotivasi.

Siklus kedua dilaksanakan dengan banyak siswa 11 orang. pada siklus II ini dan kriteria keberhasilan seperti yang ditetapkan pada siklus I. Tindakan yang dilakukan pada siklus II ini ditetapkan berdasarkan hasil refleksi pada siklus pertama. Kriteria keberhasilan siswa ditetapkan bila nilai 60 dan dari jumlah siswa yang hadir mendapat nilai rata - rata 60 - 100 . Proses pembelajara mengunakan model permainan kreatif, setelah siswa di ajarkan pembelajaran permainan kreatif.

Dari kegiatan pembelajaran tersebut peneliti mendapat hasil yang 


\section{Bestari: Jurnal Pendidikan dan Kebudayaan}

Volume 1 Nomor 2 Oktober 2020

dilakukan selama kegiatan pembelajaraan meningkatkan motivasi siswa dalam permainan bola voli. Data tersebut diatas menunjukan bahwa pembelajaraan bola voli dari jumlah siswa sebanyak 11 orang dengan persentase ketuntasan11 orang, atau $100 \%$ dan tidak tuntas sebanyak 0 orang, atau $0 \%$. Nilai pembelajaraan bola voli siswa yang paling tertinggi adalah 92,50 dan yang terendah adalah 62,50. Jumlah nilai siswa ke seluruhannya 824,50 dibagi 11 Orang maka nilai rata-rata adalah 74,95 . Dengan demikian rata-rata pembelajaran bola voli pada siklus II dikatakan berhasil. Setelah melakukan penilaian terhadap proses pembelajaran bola voli peneliti melajutkan penilaian terhadap motivasi siswa.

Data tersebut diatas menunjukan bahwa motivasi siswa terhadap pembelajaraan permainan bola dari jumlah siswa sebanyak 11 orang dengan persentase ketuntasan 100\% dan tidak tuntas $0 \%$. Nilai motivasi siswa pada pembelajaaran permainan bola siswa yang paling tertinggi adalah 100 dan yang terendah adalah 60. Jumlah nilai siswa keseluruhannya
824,50 dibagi 11Orang maka nilai rata-rata adalah 74,95. Dengan demikian rata-rata nilai motivasi siswa dalam pembelajaraan permainan bola voli pada siklus II dikatakan berhasil.

\section{Pembahasan}

Pembelajaraan permainan bola voli siswa sangatlah rendah sehingga pontensi dan prestasi individual siswa tidak terasah hal ini menyebakan pembelajaran permainan bola voli belum tercapai pada tingkat keberhasilan

Rendahnya nilai pembelajaraan permainan bola voli siswa terlihat dari kondisi-kondisi sebagai berikut: (1) Siswa kurang antusias dalam mengikuti proses pembelajaran karena pembelajaran yang berlangsung cenderung membosankan. (2) Siswa kelas V SD Negeri 09 Tanjung Lay belum mengetahui teknik dasar permainan bola voli. (3) Sarana dan prasarana yang sangat kurang untuk menunjang kelancaran kegiatan belajar mengajar. (4) Siswa hanya mendengarkan penjelasan dari guru 


\section{Bestari: Jurnal Pendidikan dan Kebudayaan}

Volume 1 Nomor 2 Oktober 2020

saat memulai pembelajaran sehingga menyebabkan siswa kurang afekif. (5) Saat proses pembelajaran berlangsung, beberapa siswa tidak serius dalam mengikuti pembelajaran.

Model permainan kreatif merupakan salah satu solusi dalam mengatasi rendahnya tingkat motivasi siswa dalam melakukan pembelajaraan permainan bola voli sebagaimana diuraikan diatas. Tindakan ini diterapkan sebanyak dua siklus terhadap siswa kelas V SD Negeri 09 Tanjung Lay, dan ternyata penelitian tentang model permainan kreatif untuk memotivasi siswa dalam Permainan Bola Voli Kelas V SD Negeri 09 Tanjung Lay menunjukan peningkatan yang signifikan.

Data tersebut di atas menunjukan bahwa terjadi peningkatan motivasi siswa pada pembelajaaran permainanbola voli, siklus I sebesar 57,73 dan pada siklus II sebesar 74,95.

Penelitian dapatlah disimpulkan dari siklus I dan siklus II dinyatakan sebagai berikut: Perbandingan tingkat ketercapaian jumlah nilai persentase dan nilai rata-rata minat motivasi siswa dalam pembelajaraan permainan bola voli service bawah pada kegiatan pembelajaran penjaskes di kelas V SD Negeri 09 Tanjung Lay menunjukan bahwa perbandingan jumlah nilai dari siklus I ke siklus II sebesar $16,81 \%$. Dengan demikian dapat disimpulkan bahwa model permainan kreatif untuk motivasi siswa pada Pembelajaraan permainan bola voli kelas V SD Negeri 09 Tanjung Lay.di katakan berhasil.

\section{SIMPULAN}

Pembelajaraan permainan bola voli sangatlah rendah sehingga pontensi dan prestasi individual siswa tidak terasah hal ini menyebakan siswa kurang termotivasi pada pembelajaran permainan bola belum tercapai pada tingkat keberhasilan. Model permainan kreatif merupakan salah satu solusi dalam mengatasi rendahnya tingkat nilai motivasi siswa dalam melakukan pembelajaraan permainan bola voli sebagaimana diuraikan diatas. Tindakan ini diterapkan sebanyak dua siklus terhadap siswa kelas V SD Negeri 09 Tajug Lay, dan ternyata penelitian tentang pembelajaraan dalam memotivasi siswa dalam pembelajaraan permainan Permainan 


\section{Bestari: Jurnal Pendidikan dan Kebudayaan \\ Volume 1 Nomor 2 Oktober 2020}

Bola Voli dengan model permainan kreatif Pada Siswa Kelas V SD Negeri 09 Tanjung Lay menunjukan peningkatan yang signifikan.

Terjadi peningkatan motivasi siswa pada pembelajaaran bola voli , siklus I sebesar 57,73 dan pada siklus II sebesar 75,54. Peningkatan motivasi siswa pada pembelajaaran permainan bola siklus I dan Siklus II dalam penelitian ini, dapat lebih jelas terlihat Perbandingan tingkat ketercapaian jumlah nilai persentase dan nilai rata-rata motivasi siswa dalam pembelajaraan permainan bola voli pada kegiatan pembelajaran penjaskes di kelas V SD Negeri 09 Tanjung Lay menunjukan bahwa perbandingan jumlah nilai dari siklus I ke siklus II sebesar 16,81 .

Dengan demikian dapat disimpulkan bahwa model permainan kreatif untuk memotivasi siswa dalam pembelajaraan permainan bola voli pada siswa kelas V SD Negeri 09 Tanjung Lay dikatakan berhasil.

\section{DAFTAR PUSTAKA}

Aip Syari Fudin \& Muhadi, 1992. Interaksi dan motivasi belajar-mengajar. Jakarta: CV. Rajawali.

Arikunto, Suharsimi. 2002. Prosedur Penelitian: Suatu Pendekatan Praktis. Edisi

Revisi V. Jakarta: Rineka Cipta.

Astuti,S.D.2006. Motivasi siswa SMP $N 2$ Jetis Bantul Dalam Mengikuti Kegiatan Ekstrakurikuler Bola voli. skripsi program studi Pendidikan Jasmani Kesehatan dan Rekreasi Fakultas Ilmu Keolahragaan Universitas Negeri Yogyakarta.

Bidang Wasit PP. PBVSI. 2001. Peraturan Permainan Bola Voli Internasional. Jakarta: PP. PBVSI.

BSNP. 2006. Kurikulum Tingkat satuan pendidikan. Jakarta: Depdikbud

Depdiknas. 2003. Standar kompetensi mata pelajaran pendidikan jasmani. Jakarta: Depdiknas

Durwachter, G. 1984. Bola Voli Belajar dan Berlatih Sambil Bermain. Jakarta: PT. Gramedia. 


\section{Bestari: Jurnal Pendidikan dan Kebudayaan \\ Volume 1 Nomor 2 Oktober 2020}

Eveline Siregar, 2010. Faktor-faktor pengaruh motivasi belajar. Jakarta: Gramedia

Gunarsa, S.D. 2008. Psikologi olahraga. Jakarta: PT. BPK Gunung muliya.

Hanafiah, N.\& Suhana, C. 2012. Konsep strategi pembelajaran. Bandung: PT Remaja Rosdakarya.

Husdarta, 2010. Teori motivasi dan ukuranya analisis di bidang pendidikan. Jakarta: Bumi Aksara.

Koesyanto, Herry.2003. Belajar bermain Bola Vol ey. Semarang: FIK UNNES.

Kosasih, E. 1993. Olahraga Teknik dan program latihan, Jakarta: Akademika Presindo.

Kusumah, Wijaya dan Dedi

Dwitagama. 2011 Mengenal Penulisan Tindakan Kelas. Jakarta: PT Indeks.

Kurniawan, Imam. 2005. Pembelajaran Pas Atas Menggunakan Sasaran Tembok Dan Berpasangan Terhadap Kecakapan Pas Atas Dalam Permainan Bola
Voli Pada Ekstrakurikuler SMP 3 Patebon Kabupaten Kendal TahunPelajaran 2004/2005. Skripsi. Jurusan PJKR, Fakultas Ilmu Keolahragaan Universitas Negeri Semarang.

Mulyasa, E. 2002. Perinsip-perinsip dan teknik evaluasi pengajaran. Bandung: PT Remaja Rosdakarya.

Muhajir, 2006.Pendidikan Jasmani Olahraga dan kesehatan. Jakarta Erlangga

Mylsidayu, A. 2014. Pisikologi olahraga. Bumi Aksara: Jakarta.

Nuril Ahmadi, 2007.mendesain model pembelajaran inovatif-progresif. Jakarta: kencanaPrenanda Media Group.

Nurhasan.2001. Tes dan Pengukuran Dalam Pendidikan Jasmani: Prinsip-

Prinsip dan Penerapanya. Jakarta: Diknas nem Dirtjen Olahraga. Poewadarminta, 2003.Prinsip-prinsip dan teknik evaluasi pengajaran. Bandung: PT Remaja Rosda Karya. 


\section{Bestari: Jurnal Pendidikan dan Kebudayaan}

Volume 1 Nomor 2 Oktober 2020

Purwanto, N.2004. Psikologi pendidikan. Bandung: PT Remaja Rosda karya.

Purnama. 2016. Motivasi Mengikuti Permainan Bola Basket dalam Pembelajaran Pendidikan Jasmani Olah raga dan Kesehatan Peserta Didik Putri Kelas XI SMA Negeri 2 Wonogiri Jawa Tengah.

Rusman, 2010.Model-Model Pembelajaran. Jakarta: Raja Grafindo Persada.

Sardiman, A.M 1990.interaksi dan motivasi

belajar-mengajar.jakarta:CV.

Rajawali

Shadiq, 2010. Pengertian kreativitas dan belajar adaptif (online).

http://fkip-unpak.Org/teti. html

Slameto, 2003. Belajar dan faktor-faktor yang mempengaruhinya.Jakarta:

Rineka cipta.

Soemitro, 1992. Implementasi belajar \& pembelajaran. Bandung: Remaja Rosda Karya.
Suharno, H.P.1993.Ilmu coaching umum. Yogyakarta: IKIP Yogyakarta Pres

Sukintaka,1992. Teori pendidikan jasmani. Yokyakarta:Esa Grafika.

Suyono \& Hariyanto, 2015. Implementasi belajar \& Pembelajaran. Bandung: Remaja Rosdakarya.

Trianto, 2009. Mendesain Model Pembelajaran Inovatif-progresif. Jakarta: Kencana Prenanda Media Group

Uno, H.B.2014.Teori Motivasi Dan Ukurannya analisis di bidang pendidikan. Jakarta: Bumi Aksara.

Walgito,B. 2003. Pengantar pisikologi umum. Yogyakarta: ANDI.

Wiriaatmadja, Rochiati. 2009. Metode penulisan tindakan Kelas. Bandung: PT. Remaja Rosdakarya.

Yunus, M. 1992. Olahraga pilihan bola voli.Jakarta: Dirjen Dikti Debdikbut. 


\title{
PENERAPAN PERMAINAN KASVO UNTUK MENINGKATKAN MOTIVASI PEMBELAJARAN BOLA VOLI PADA SISWA KELAS IV SDN 18 TANJUNG SARI
}

\author{
Mariana $^{1}$, Kurnia Dyah Anggorowati ${ }^{2}$, Suyatmin $^{3,}$ \\ ${ }^{1}$ Mahasiswa Program Studi Penjaskesrek \\ 2,3 Dosen STKIP Melawi \\ J1. RSUD Melawi km. 04 Kec.Nanga Pinoh Kab. Melawi Kalimantan Barat \\ kurniadyah12@yahoo.com, suyatminuny@gmail.com
}

\begin{abstract}
Abstrak: This study aims to improve students' motivation and learning gains in conducting learning the volley ball through the application of game KASVO in class IV SDN 18 KKLK Tanjung Sari Nanga Pinoh.Method in a study should be right or lead to the research objectives and can be scientifically accounted results ar a expeted. The method used in this research is a class act.Based on the results of the research after the act of classed,the data showed that the acquisition of the percentage of learning motivation of fourtg grade students in class IV SDN 18 KKLK Tanjung Sari on the 1 st cycle by $45 \%$, success rate including less, are includedin the qualification success rate is quite good. The precentage of motivation for your teen to lear the fourth grade studentd in class IV SDN 18 KKLK Tanjung Sari on the second cycle of $85 \%$ is included in the qualification success rate"good" It can be conclude that the implementation of the game kasvo to improve the motivation to learn of students in learning volleyball on the students of class IV SDN 18 KKLK Tanjung Sari Nanga Pinoh said increasing
\end{abstract}

Key words: Student Motivation, Game KASVO, Learning Volley Ball.

\begin{abstract}
Abstrak: Tujuan penelitian ini adalah untuk mengetahui peningkatan motivasi belajar siswa serta perolehan hasil belajar siswa dalam permainan bola voli dengan penerapan permainan KASVO pada siswa kelas IV SDN 18 KKLK Tanjung Sari Nanga Pinoh. Metode dalam suatu penelitian harus tepat atau mengarah pada tujuan penelitian serta dapat dipertanggung jawabkan secara ilmiah sesuai dengan aturan yang berlaku, agar dalam penelitian tersebut dapat diperoleh hasil yang sesuai dengan yang diharapkan. Metode penelitian yang digunakan dalam penelitian ini adalah penelitian tindakan kelas. Berdasarkan hasil dari penelitian setelah dilakukan tindakan kelas, data menunjukanbahwaperolehanPresentase Motivasi belajar siswa kelas IV SDN 18 KKLK Tanjung Sari pada siklus I sebesar $45 \%$ tingkat kebehasilan termasuk kurang, termasuk dalam kualifikasi tingkat keberhasilan" cukup baik" .Presentase Motivasi belajar siswa kelas IV SDN 18 KKLK Tanjung Sari pada siklus II sebesar 85\% termasuk dalam kualifikasi tingkat keberhasilan "baik" Dengan demikaian dapat disimpulkan bahawa penerapan permainan KASVO untuk meningkatkan motivasi belajar siswa dalam pembelajaran bola voli
\end{abstract}


pada siswa kelas iv SDN 18 KKLK Tanjung Sari Nanga Pinoh dikatakan berhasil.

Kata Kunci: Motivasi Siswa, Permainan KASVO, Pembelajaran bola voli.

$\mathrm{B}$ erdasarkan hasil observasi peneliti di SDN 18 KKLK Tanjung Sari, pada siswa kelas IV. Banyak sekali pengalaman yang peneliti peroleh dari kegiatan tersebut, baik pada saat proses pembelajaran pendidikkan jasmani olahraga dan kesehatan khusus mata pelajaran bola voli berlangsung, yaitu: masih kurangnya siswa yang gemar dengan olahraga bola voli data ini diperoleh data kuisioner yang dikumpulkan dari siswa, kurangnya semangat belajar siswa dilihat dari tidak adanya siswa yang aktif bertanya dalam proses pembelajaran, siswa yang ribut, acuh tak acuh, siswa sering keluar masuk kelas ketika jam pelajaran, rendahnya pemahaman siswa tentang permainan bola voli, proses pembelajaran atau metode yang digunakan oleh guru kurang bervariasi, permainan kasvo belum pernah diterapkan

Melihat masalah tersebut, maka perlu diterapkan suatu sistem pembelajaran yang melibatkan peran siswa secara aktif dalam kegiatan belajar mengajar guna menumbuhkan motivasi belajar siswa. Motivasi belajar adalah keseluruhan daya penggerak baik dari dalam diri maupun dari luar siswa (dengan menciptakan serangkaian usaha untuk menyediakan kondisi-kondisi tertentu) yang menjamin kelangsungan dan memberikan arah pada kegiatan belajar, sehingga tujuan yang dikehendaki dapat tercapai.Motivasi belajar diperlukan oleh seorang siswa dalam mempelajari suatu materi atau pokok

Kasvo merupakan salah satu bentuk modifikasi pembelajaran bola voli yang dikemas dalam sebuah permainan kasti yang dimodifikasi. Sesuai dengan namanya kasvo merupakan perpaduan dari dua kata yakni kasti dan voli, berbeda dengan permainan kasti pada umumnya permainan kasvo tidak menggunakan pemukul dan bola kasti namun menggunakan bola spons atau bola voli. Tujuan permainan kasvo ini adalah untuk membuat pembelajaran servis bawah bola voli menjadi sebuah permainan kompetisi yang menyenangkan namun tetap sesuai dengan tujuan gerak dasar yang ingin dicapai, Sehingga siswa terbiasa 
melakukan servis bawah tanpa tertekan oleh tuntutan harus melewati net atau masuk kelapangan seperti pada permainan bola voli pada umumnya.

Motiv dapat diartikan sebagai suatu kondisi internal (kesiapan, dan kesiagaan), yang berawal dari kata "motiv" itu, maka motivasi dapat diartikan sebagai daya penggerak yang telah aktif pada saat-saat tertentu terutama apabila kebutuhan untuk mencapai tujuan sangat dirasakan mendesak.

Soemanto (dalam Abdul Majid, 2014:307 secara umum mendefinisikan motivasi sebagai suatu perubahan tenaga yang ditandai oleh dorongan efektif dan rekreasi-rekreasi pencapaian tujuan. Akan tetapi prilaku manusia itu selalu bertujuan, karena itu dapat menyimpulkan bahwa perubahan tenaga yang memberi kekuatan bagi tingkah laku mencapai tujuan telah terjadi di dalam diri seseorang.

Menurut Uno (2015 : 23) Motivasi dan belajar merupakan dua hal yang saling mempengaruhi. Belajar adalah perubahan tingkah laku secara relatif permanen dan secara potensial terjadi sebagai hasil dari praktis atau penguatan (reinforced practice) yang dilandasi tujuan untuk mencapai tujuan
tertentu.Teori motivasi dan pengukurannya analisis dibidang pendidikan.

Belajar merupakan proses perubahan perilaku secara aktif, proses mereaksi terhadap semua situasi yang ada di sekitar individu, proses yang diarahkan kepada suatu tujuan, proses berbuat melalui berbagai pengalaman, proses melihat, mengamati, memahami sesuatu yang ingin dipelajari (Gino, dkk: 1998: 31).

Menurut reigeluth dan carr-chellman dalam Muhammad Yaumi (2013:57) pembelajaran dapat didefinisikan "as anything that is done purposely to facilitate learning, Artinya, pembelajaran dapat dipahami sebagai segala sesuatu yang dillakukan maksud untuk memfasilitasi belajar. Pembelajaran juga dipahami sebagai upaya yang disengaja untuk mengelola kejadian atau peristiwa belajar dalam memfasilitasi peserta didik sehingga memperoleh tujuan yang dipelajari.

Dari berbagai pendapat di atas dapat disimpulkan bahwa motivasi belajar adalah kesanggupan untuk melakukan kegiatan belajar karena didorong oleh keinginannya untuk memenuhi kebutuhan dari dalam dirinya ataupun yang datang dari luar. Kegiatan 
itu dilakukan dengan kesungguhan hati dan terus menerus dalam rangka mencapai tujuan.

Motivasi belajar siswa dapat dianalogikan sebagai bahan bakar untuk menggerakkan mesin motivasi belajar yang memadai yang lakan mendorong siswa berperilaku aktif untuk berprestasi dalam kelas.

\section{METODE PENELITIAN}

Penelitian ini merupakan penelitian tindakan kelas pada pendidikanjasmani. Dalam penelitian ini digunakan modifikasi permainan KASVO pada pembelajaran bola voli. Pada penelitian ini yang menjadi subjek dalam penelitian ini adalah siswa kelas IV SDN 18 KKLKTanjung Saridengan jumlah siswa 20 siswa terdiri dari 11 siswa laki-laki dan 9 siswa perempuan. Prosedur penelitian ini menggunakan metode penelitian tindakan kelas dengan model John Elliot yang meliputi perencanaan, pengamatan, pelaksanaan, dan refleksi. Teknik pengumpulan data dalam penelitian ini adalah menggunakan teknik non tes dalam bentuk lembaran observasi. Dalam penelitian ini lembaran observasi digunakan untuk melihat keterlaksanaan proses pembelajaran guru dan siswa dalam proses pembelajaran, sedangkan lembar observasi motivasi digunakan untuk mengukur motivasisiswa dalam pembelajaran bola voli dengan menggunakan permainan kasvo.

Instrumen yang digunakan untuk mengumpulkan data dalam penelitian ini terdiri dari 3 macam yaitu lembar observasi keterlaksanaan RPP, lembar angket motivasi belajar siswa dan tes hasil belajardengan kisi-kisi sebagai berikut; Lembar observasi keterlaksanaan RPP digunakan untuk mencatat semua kegiatan selama pembelajaran berlangsung, baik kegiatan guru sewaktu mengajar, maupun respon siswa sewaktu belajar dan keaktifan siswa sewaktu pembelajaran berlangsung. Angket motivasi belajar siswa digunakan untuk mengukur motivasi belajar siswa pada saat pembelajaran berlangsung dengan menggunakan permainan kasvo, ada 36 soal Angket dilampirkan,dan keterangan pilihan jawaban. Aspek -aspek yang diamati adalah :

1. Perhatian (Attention)

2. Relavansi(Relavance)

3. Percaya diri(Confidence)

4. Kepuasan(Satisfication)

Analisis data merupakan langkah penting dalam penelitian, karena merupakan upaya dalam mencari dan 
menata sistematis catatan hasil penelitian, karena dalam penelitian ini merupakan nilai dalam suatu tes dan data yang terkumpul, maka objektivitas dari hasil penelitian akan lebih terjamin. Analisis data dapat memberikan efisiensi dan efektifitas kerja karena dapat membuat data lebih ringkas bentuknya.Data yang dikumpulkan pada kegiatan observasi proses pembelajaran akan diolah sebagai berikut:

\section{Data lembar observasi}

Lembar observasi ini dibuat untuk melihat sejauh mana guru dan siswa dapat melakasanakan proses kegiatan belajar mengajar data hasil observasi keterlaksanaan RPP dengan rumus:

Persentase RPP = $\frac{\text { Jumlah Skor Perolehan Kegiatan }}{\text { Total Skor Ideal }} \times 100 \%$

Sumber : Jurnal STKIP Melawi

\section{Data angket}

Data angket dianalisis dengan perhitungan, jumlah skor yang diperoleh dibagi dengan skor total dikali seratus persen. Menghitung skor rata-rata gabungan dari kriteria positif dan negatif setiap kondisi, kemudian menentukan kategorinya dengan ketentuan skor rata-rata 1,00 -1,49 =tidak baik, 1,50 2,49 =kurang baik, 2,50 - 3,49 =cukup baik, 3,50 - 4,49=baik, dan 4,50 - 5,00 =sangat baik.

\section{HASIL DAN PEMBAHASAN}

Deskripsi penelitian terdiri dari dua siklus secara berulang yang meliputi siklus I dan siklus II. Setiap siklus dalam penelitian ini meliputi empat tahap sebagaimana yang dikemukakan oleh Lewin dalam Kusmah \& Dwitagama (2010:20). Yaitu perencanaan (planning), pelaksanaan (acting), pengamatan (observing), dan refleksi (reflecting). Setelah peneliti melakukan prosedur Penelitian Tindakan Kelas (PTK), maka diperoleh hasil penelitian yang terbagi ke dalam dua siklus, yaitu siklus I dan siklus II. Hasil kedua siklus akan dijelaskan sebagai berikut.

\section{Hasil Tindakan Siklus I dan Siklus II}

Siklus I mencakup dua kali pertemuan, pertemuan pertama mulai dilaksanakan pada hari selasa tanggal 5 April 2017, dan pertemuan kedua dilaksanakan pada tanggal 12 April 2017, yang dihadiri oleh 20 orang siswa, satu orang observer yakni guru PENJASKES kelas IV di sekolah tersebut dan satu orang dokumenter yakni teman sejawat peneliti

Siklus II mencakup dua kali pertemuan, pertemuan pertama mulai dilaksanakan pada hari selasa tanggal 19 April 2017, dan pertemuan kedua dilaksanakan pada tanggal 26 April 